\title{
TERCEIRO MILÊNIO: MISTICISMO OU RESISTÊNCIA?
}

O homem está há um ano e meio do século XXI. Nas diferentes áreas de atividades, especificamente saúde, educação e meio ambiente, muitas metas tinham nesta data um prazo para o seu alcance. Este marco assinalado parecia ter uma força de esperança diferente, quase mistica, transcendental.

Assim, documentos foram escritos, planos traçados. Vislumbrou-se propósitos que tinham a intenção de colocar as sociedades brasileira e latinoamericana em patamares que elevassem as condições de vida das pessoas desta parte do planeta.

Transcorrido o tempo, aproxima-se a hora da verdade. Sem o véu da mística do fim de século, têm-se que encarar os fatos tais como se mostram.

Embora a ciência produzida nos últimos cem anos tivesse avançado e surpreendido a todos, superando as perguntas e as dúvidas propostas pelos pensadores do século XIX, a humanidade que habita este planeta distribuiu-se em diferentes territórios, com desigualdades alarmantes de acesso a bens de sobrevivência.

A dominação dos paises ricos sobre os menos desenvolvidos e mais pobres tem nas leis do mercado internacional uma arma potente em favor da recolonização econômica com mais efeitos depredativos e segregatórios que qualquer arsenal bélico militar.

As imposições do Fundo Monetário Internacional - F.M.I. - apresentam-se como código de conduta moral de governo e ética financeira mundial. Enfim, o último recurso aos paises aspirantes à independência econômica, que ao submeterem-se as suas regras, aceitam passivamente a "agiotagem" daqueles que lucram com o nosso eterno e ingênuo sonho de honestidade em eliminar a divida internacional.

Bem típico dos despossuidos, considera-se que o pagamento de juros mesmo sem o abatimento da divida básica melhora a imagem dos países que almejam mudar de casta, como se isso fosse permitido.

Cientes desta situação e sabedores que nós da América Latina somos os permanentes devedores dependentes, mesmo quando cumprimos toda lição ditada pelos credores - privatização das empresas estatais, mesmo as 
produtivas e exitosas, mudanças das regras do sistema da previdência, estimulo ao seguro privado de saúde e ao ensino privado, desativaç pequenas empresas já instaladas e outras alteraçōes cornstitucionais e mudanças das regras politicas em plena crise, como é o caso da reeleição nenhuma concessão é feita pelos senhores do mundo, apesar da divida externa estar sendo paga muitas vezes, por várias formas de coerção e vantagens comerciais impostas há muitos anos.

Contudo, o risco que corremos só aumenta e a ganância extorquidora não tem limites. O novo manifesto do Capitalismo Mundial vem se insinuando através do Acordo Mundial de Investimento (AMI). Para Barbosa Lima Sobrinho um dos mais terriveis instrumentos de recolonização que vêm sendo preparado desde 1995, sigilosamente, pela Organização de Cooperação e Desenvolvimento Econômico (OCDE), que congrega os 29 paises mais ricos e desenvolvidos do Mundo. Este acordo coloca os mais pobres sob severas imposições do imprescritivel direito do mais forte. Intervenções dos investidores se sobrepujarão ao poder dos governos.

Assim, qualquer sucesso que tenhamos logrado nas últimas décadas na relação entre governo e sociedade e alguns programas competentes, ficam comprometidos com qualquer possibilidade do Brasil assinar este acordo.

Portanto, resta-nos a única meta de final de século a ser alcançada pelos povos latino-americanos: resistir, organizar-se e não se submeter às regras do grande capital mundial. Qualquer outra meta é mera fantasia ou ficção do $3^{\circ}$. milênio.

Maria Therezinha Nóbrega da Silva 